\title{
Small and Medium Enterprises (SMEs) Competing in the Global Business Environment: A Case of Malaysia
}

\author{
Mohd Zulkifli Muhammad (Corresponding author) \\ School of International Business and Finance Labuan \\ Universiti Malaysia Sabah, Labuan International Campus, 87000, F.T Labuan, Malaysia \\ Tel: 60-87-460-498 E-mail: zulrider@yahoo.com
}

\begin{abstract}
Abdul Kamal Char
School of International Business and Finance Labuan

Universiti Malaysia Sabah, Labuan International Campus, 87000, F.T Labuan, Malaysia
\end{abstract}

Tel: 60-87-460-525Ｅ-mail: abdkamal@ums.edu.my

Mohd Rushdan bin Yasoa'

School of International Business and Finance Labuan

Universiti Malaysia Sabah, Labuan International Campus, 87000, F.T Labuan, Malaysia

Tel: 60-87-466-714 E-mail: rushdan@ums.edu.my

Zakiah Hassan

School of International Business and Finance Labuan

Universiti Malaysia Sabah, Labuan International Campus, 87000, F.T Labuan, Malaysia

Tel: 60-87-460-820 E-mail: zakiah_hassan78@yahoo.com

\begin{abstract}
Small and Medium Enterprises (SMEs) play a vital role in the country's economic development. The current trend of economic growth and the rapid industrial development has made Malaysia as one of the most open economies in the world. In conjunction with the Ninth Malaysian Plan (2006-2010), the government is devoting and designing the SME development plan to assist the SMEs to meet the new business challenges in the competitive global business environment. The focus of this paper is the discussion of the competitiveness facing SMEs in the global business environment by examining the opportunities and supports from the government. Furthermore, this study also analyses the challenges of Malaysian SMEs in globalize market together with economics turmoil.
\end{abstract}

Keywords: Small and Medium Enterprises (SMEs), Challenges, Competitiveness, Globalization

\section{Introduction}

It is apparent that small and medium enterprises (SMEs) play a vital role in the economic development of a country. The current trend of economic growth and the rapid industrial development has made Malaysia as one of the most open economies in the world. In conjunction with the Ninth Malaysia Plan (2006-2010), the government is devoting and designing the SME development plan to assist the SMEs to meet the new business challenges in the competitive global business environment.

There is no doubt that economic activities are moving in the direction of globalization. The system of production and distribution is evolving worldwide. The important role that international trade plays in connecting countries around the world is clear. Globalization creates new structures and new relationships, with the result that business decisions and actions in one part of the world have significant consequences in other places. Underlying and reinforcing these globalization trends is the rapidly changing technological environment, particularly in information processing, and telecommunications. Changes in telecommunications and data processing capabilities make it possible to coordinate research, marketing and production operation around the world. Almost instantaneous communications make it possible to trade financial instruments twenty-four hours a day, and thus more return-sensitive are location of resources within firms, industries and countries. 
The growth of global markets stimulates competition and forces governments to adopt market-oriented policies, both domestically and internationally. Modern technologies have greatly reduced the cost of information and the capabilities to participate in the global economy. In fact, there is ample evidence that SMEs has not only flourished in domestic economies, but that their international presence has grown as well. An overview of SME participation in the global economy reveals at least three lines of activity: trade, technology, and investment. The most commonly discussed topic in SMEs international literature is their role as exporters from their domestic jurisdictions to foreign customers. The opportunities and challenges facing SMEs in this role are well known. The second most prominent issue in the literature is SMEs and technology, and particularly SME supplier connections with larger Multi National Enterprise (MNEs) in local markets. If small firms face higher barriers to entry in international operations than large firms, and have a more difficult time protecting their property rights, how can small firms become international players? When SMEs invest abroad, they generally seek help from larger corporations. Gomes-Casseres (1997) examines the use of strategic alliances by SMEs. He asks three questions: (1) when do small firms use alliances to do business abroad, (2) how do small businesses use alliances, and (3) what effect do alliances have on firm's competitive performance?

Internationalisation of the production and distribution of goods and services, and the associated trade and capital flows, has accelerated in most countries during the past 15 to 20 years. This process has been loosely described as "globalization". However, it has been broadly accepted as a set of activities associated with the multinational or direct foreign investing firm which integrates its activities across national borders to maximize the profits or interests of the group. More simply, it can be the broader opening up of national economies to the international marketplace (EPAC, 1995a; 1995b). It is believed that globalization is actually not a new phenomenon since international trade, foreign direct investment and associated movement of capital, management and labor has been going on for centuries. If globalization is defined as being the broader opening up of national economies to the international marketplace, then it has implications for small firms as well as large. Increased participation of small firms in the international marketplace can be seen as an important part of globalization.

Central Bank of Malaysia findings based on case studies done on the SMEs with more than 10 years in business (Central Bank of Malaysia, 2003), shows that the key success factors of SMEs in the globalize space environment are as follows:

i. Sound management capability and integrity

ii. Sound business cultures and entrepreneurial spirit

iii. Prudent financial management

iv. High quality products and services

v. Effective program for human resource development

vi. Strong support from financial institutions (in terms of lending and advisory services)

vii. Strong marketing strategies (including good network with suppliers)

viii. Continuously looking for opportunities to expand

The structure of this paper is arranged as follows; section 1 introduces the paper, section 2 briefly describes the background of SMEs in Malaysia. Section 3 discusses the challenges facing by SMEs in globalize market together with economics turmoil. Section 4 analyses the competitiveness of Malaysian SMEs in the global business environment by examining the opportunities and supports from the government, while section 5 concludes the paper.

\section{An overview of small and medium enterprises (SMEs) in Malaysia}

According to Small and Medium Industries Development Corporation (SMIDEC), an enterprise is considered as an SME in each of the representative sectors based on the annual sales turnover or number of full time employees. SMEs are divided into two sectors; manufacturing, manufacturing related services and agriculture industries; and services (including ICT) and primary agriculture. From Table 1.1, an improved definition of enterprises in respond to the rapid changing of the industry of globalization is provided. It is more specific to a particular industry, which is adopted by all commercial banks, ministries and government agencies at federal and state levels. However, it is noted that during the past 7 years, the definitions of SMEs have changed thrice. In 1999, the SMEs was defined as Malaysian owned companies/ institutions with net assets or shareholders funds of RM10 million whilst prior to that the shareholders funds or net asset was limited to RM2.5 million. The frequent changes in the definition of SMEs have also affected the formulation of long-term strategy for SMEs development.

Meanwhile, with reference to Table 1.2, Malaysian Department of Statistics has divided the distribution of establishment by sector, namely; manufacturing, services and agriculture. The highest distribution is from service $(87.9 \%)$, followed by agriculture $(7.1 \%)$ and manufacturing $(5 \%)$. 


\section{Challenges facing Malaysian SMEs in the global business environment}

Several of the existing literature, including Saleh \& Ndubisi (2006); Samad (2007); Abu Bakar et al. (2006); Aris (2006); Harvie (2004); Wang (2003); Stuti (2005); Wafa et al. (2005); Ritchie \& Brindley (2000); Decker et al. (2006); Foon (2006); and SMIDEC (2007), emphasize various challenges facing SMEs in a globalized environment, for example from difficulty in facing recession, barrier from global sourcing, low productivity, lack of managerial capabilities, lack of financing, difficulty in accessing management and technology, heavy regulatory burden and others. In the other study, Teoh \& Chong (2008) found the barriers to entrepreneurship namely lack of access to credit and lack of access to formal business and social networks. Besides, SMEs are dealing with intensified global challenges, new emerging technologies in ICT and production process as well as increasing factor costs, which affect the export competitiveness.

SMEs are classified into three different categories according to their capability and their success walking through the challenges. Firstly, a group of SMEs that is viable or able to become internationally competitive, may gain the benefit from the regionalization (McMahon, 2001). The second group is SMEs that are less adaptable to the globalization pressure. They are unlikely to survive in the present situation without making fast move to improve productivity, to conform to international standards, to train and employ skill management and professional staff to face competitions. The third group is SMEs that are protected by the government from the globalization effect (Samad, 2007).

\subsection{Recession}

Economic downturn has been a constant challenge facing SMEs. Since the year 2007, the world economy experienced several unfavorable events such as boiling oil prices followed by sub-prime credit crunch in the USA, which leads to a financial distress to the financial market. Most nations are currently showing a diminishing economic growth and increasing costs of production, which indicates that recession is unavoidable. The common aftermaths of a recession are lower expenditures by consumers, lower demand for products and services, lower productions and job cuts. SMEs, small in nature, are affected in larger degree especially those involved with trading and supplying products or services to other businesses. Lower cash flows and limited financing are the major challenges faced by the SMEs during this bearish period. However, evidence from other regional economies suggests that SMEs came through the crisis better than large enterprises. The avoidance of a future crisis could, therefore, depend upon developing a competitive SME sector that is able to compete in both domestic and external markets. Harvie (2004) argues that the SME sector has a crucial role to play in the sustained recovery of the region arising from the business opportunities created by the restructuring process itself, the movement towards closer regional economic integration, advances in information and communications technology (ICT) and more specifically the business opportunities arising from the Internet.

\subsection{Global sourcing}

Globalization and liberalization has made business resources more mobile and transferable beyond borders. Competition for resources such as material and capital has increased in many Asian countries including Malaysia. Levitt (1983) in his article on the globalization of markets has emphasized that companies must learn to operate as if the world is one large market ignoring superficial regional and national differences. In the process, globalization promotes technology, source and knowledge transfer, as ever-new processes of production and services will be provided. Globalization also promotes the rapid innovation, easy entry as less government protection and convergence across industries due to less trade barriers within region, constant arrival of new range of products and liberalization opening up of new economies (Humprey, 2001). Besides all the good deeds, liberalization harms local SMEs as they have to compete with cheaper, more innovative incoming foreign products or services and compete for resources and capital. Globalization also creates unprecedented information and communication technologies (Abu Bakar et al., 2006). In contrary, globalization also requires an efficient risk management, relationship marketing, and supply chain management (Ritchie \& Brindley, 2000). The objective of these fields are to reduce uncertainty, identify potential risks, elicit better quality information, and improve understanding of the competitive global environment. Eventually, SMEs need to improve their competitive capability by the effective measuring in collaborative environments (Alba et al., 2005). Therefore, SMEs must take advantage of low labor cost, flexible logistics, new technology, cheaper materials and of less regulated operating environment. This in return provides synergy to small and medium enterprises in the emerging countries like Malaysia.

\subsection{Lack of state government support}

The state government needs to play an important role and commitment to SMEs, especially in key growth areas as well as the available assistance and infrastructure to support them (SMIDEC, 2007). One such area is the Halal industry. Many of state governments in Malaysia did not attempt to encourage Halal industry. For example, Negeri Sembilan and Melaka state still allowing pig farming without concerning the Halal industry on aggregate basis. With estimated figures for Halal trade of USD2.1 trillion, there is staggering potential for Halal products globally. The state government must recognize this potential as it prepares Malaysia towards becoming the international Halal Hub by 2010. Other key 
growth areas include the growing franchise industry and the current trend of shared services and outsourcing (SSO) (Central Bank of Malaysia, 2003). These areas are also need to be addressed and taken into consideration by all state governments to ensure the successful of the proposed national agenda (Teoh \& Chong, 2008).

\subsection{Relationship between multinational corporations (MNCs) and SMEs}

SMEs in Malaysia does conduct some businesses with MNCs either in large or small scales, as a vendor or franchisee. If the existing MNCs are moving out of the country, because of the liberalization of the market, to lower labor cost countries like China and India, SMEs will lose business and trigger "vicious circle" between the foreign direct investment and SMEs. This is in view that if a MNC is shifting out, some SMEs may close down and other MNCs also could not source some parts and components (Samad, 2007). From the other perspective, the extensive research has examined the factors that influence the international expansion and success of MNCs, but Knight (2000) breaks new ground by focusing on the internationalization of small entrepreneurial firms. Using data from an empirical study of 268 SMEs, he devises a structural model that reveals the role of international entrepreneurship orientation. His findings imply that international entrepreneurial orientation is an important driver of several important parameters, key to the international performance of the small firm. Among these are internationalization preparation, strategic competence, and technology acquisition. Hence, the government needs to undertake certain strategic actions to sustain the existing MNCs due to their significant role in the economy and for SMEs to survive and prosper.

\subsection{Intellectual property and bankruptcy issue}

SMEs in Malaysia are not really exposed and concerned to the important of protecting intellectual property in meeting the challenges due to globalization. However, a study by Kitching \& Blackburn (1998) highlighted that SMEs owners placed most emphasis on informal methods to protect intellectual property. These methods were more familiar, cheaper, less time-consuming and frequently considered as effective as more formal rights. As for SMEs, the formal recognition and registration often considered to be uneconomical in order to enforce their rights through the existing legal system. They need to protect their intellectual property in a cost effective way. This is a setback when gigantic companies took over their rights. In terms of bankruptcy arrangements, many entrepreneurial ventures are not a success, but they are not necessarily failures in the sense of losing money. It makes sense to try to make markets contestable by reducing exit costs and impediments for ventures that are not up to initial expectations (Samad, 2007).

\subsection{Legal issues in global business}

Given the global market, SMEs are facing the lack of knowledge on legal matters, and in Malaysia, there is no body or agency that advises matters pertaining to legal specifically to SMEs going abroad. Teoh \& Chong (2008) found the barriers of SMEs entrepreneur were lack of access to gain management experience and exposure in regards with international rules and regulations. Hence, SMEs may find access is restricted because of obsolete and inappropriate regulations. In terms of registration and legal incorporation, many of these SMEs need to establish a presence in a foreign market in order to be visible to customers. Registration and legal incorporation requirements vary considerably amongst countries, and are often unnecessarily complex and expensive (Abu Bakar et al., 2006). It may also take a longer time for SMEs to obtain reliable information about market opportunities and relevant regulations for new products, services or techniques. In addition, there are certain specific requirements or controls imposed by foreign governments (Aziz, 2000).

\subsection{Decision process and $R \& D$ landscape in SMEs}

Large corporation commonly spent substantial amount of money hiring consultant or setting up business development division comprise of trained personnel to make major decisions about any business matters. SMEs on the other hand are often hurdled by their limited capital for business development of R\&D. Since innovation is crucial in R\&D aspect, SMEs owner may diagnose their current business position and strategically plan intended changes by enhancing their operational capabilities. Most importantly, they may strive to take practical steps to evolve from efficiency SMEs all the way to innovation SMEs (Hong \& Jeong, 2006). In addition, the owner of the SMEs usually makes vital decisions such as investing for the expansion of the business or venturing into new market. Furthermore, integrated R\&D has a possibility to reap economies of scale in global production networks (Coe et al., 2004). Without adequate knowledge, information and systematic analysis, it is even harder to assess potentials and threats of the global business to the companies. In terms of research and development, it is mainly aimed at the needs of big enterprises, so there is often a lack of know-how about any latest and new emerging technologies including Internet in SMEs (Decker et al., 2006). While Internet technologies are global and their core is standardised, their applications can and need to be adapted to local circumstances (Tetteh \& Burn, 2001). Internet offers this amazing capability to reconcile global uniformity and local flexibility. It facilitates cross border links, but at the same time creates new configurations of networks and clusters (Indjikian, 2003). This in turn, SMEs will be encouraged to use online banking and payments services as a part of their common business practices. 


\subsection{Branding the products in the global market}

Branding is a way of differentiating products or services from others and making the products attractive to customers. SMEs in Malaysia do not consider branding as their utmost strategy to compete globally. Less capital and effort invested in making products more attractive and well packaged, as well as product innovation particularly for export market. Companies may achieve competitive advantage through acts of innovation and innovation can be in the form of new product design, new production process or new marketing approach (Foon, 2006). SMEs need to strengthen the branding to better position themselves to penetrate new market opportunities. SMEs may also actively distribute its products through franchise if a recognized brand is established.

Therefore, SMEs need to revolutionize, adopt and adapt in order to compete and remain relevant in the emerging and challenging economies. SMEs also need to reinforce the domestic industry to better position themselves to make a way into global market opportunities. Competitive and resilient SMEs are important in the growth and development process of the Malaysian economy including the adoption of appropriate strategy. According to Wafa et al. (2005), the differentiation strategy was found to have the relationship with the performance and competitiveness of SMEs. Moving forward, SMEs have great potential to be the engine of the economic growth as could be seen in other developed countries both in the East and in the West like Germany and Japan (Samad, 2007).

The strategy practices by SMEs in Malaysia are pertinent to be competitive in the global market.

\section{Competitiveness of SMEs in the global business environment: a government supports}

Similar to the MNCs, SMEs are proven to play a significant role in the economic stability and growth of a nation. SMEs is an important segment of the Malaysian economy accounting for $99.2 \%$ of total business establishments, employing 5.6 million of the work force and contributing about 32\% of gross domestic product (BNM, 2008). Most SMEs require support or assistance from the government especially to be more competitive in the global business environment. The role of government is to encourage companies to move to higher levels and gain competitive advantage in the globalise space environment (Samad, 2007). The government of Malaysia, through its many agencies deployed several measures and platforms to assist SMEs in managing the impact of higher costs on their production, slower turnover and financial distress.

The National SME Development Council (NSDC) was established in June 2004 by the government to assist the SMEs. The NSDC acts as the highest body to formulate strategies, to provide direction and coordinate development of SMEs. It also guides and oversees SME development initiatives to ensure effectiveness in strategies implementation. The NSDC is chaired by the Prime Minister and comprises 16 Members of Cabinet and Heads of 3 Agencies involved in SME development. Bank Negara Malaysia serves as the secretariat to the Council. Up to beginning of 2009, the NSDC has implemented several initiatives to strengthen the SMEs.

In 2007, more than 286,000 SMEs has been assisted through 189 development programs initiated by NSDC involving total expenditure of RM4.9 billion. These development programs, guided by the SME Blueprint Management Framework, provide business support services, entrepreneurship training, technical training, business premises and factories. The framework has improved collaboration between ministries, agencies and SMEs involved, and has made SME development programs more effective, successful and beneficial.

Beside development programs, the NSDC has also emphasized on financial assistance to SMEs. Through Bank Negara Malaysia, the council has implemented several measures to enhance access to financing by SMEs. There are 26 agencies, 2 ministries and 9 banking institutions involve in providing financial assistance to SMEs in form of soft loans, grants, equity financing, venture capital, guarantee scheme and tax incentives. SMEs may take the financing for the purpose of entrepreneur development, marketing and promotion, strengthening skills of workforce, product development, quality accreditation, technology development, debt restructuring and other general business development. The Central Bank of Malaysia, on behalf of the council granted incentives such as credit guarantee to private banking institutions as to encourage them to be part of this program.

In the meantime, strong credit history and performance of the SMEs has made financing more attractive and less risky to the banking institutions. Record shows that in 2007, non-performing loan ratio declined to $9.1 \%$ from $11.1 \%$, and a total of RM63.2 billion financing was approved to more than 132,000 SMEs by banking institutions and development financial institutions (BNM, 2008). In order to further improve the financial support to microentrepreneurs, the government has launched the National Microfinance Logo in October 2007 as another financing option for SMEs, provided by nine financial institutions. As a result, over 26,000 micro enterprises have grabbed the opportunity with total micro financing outstanding was RM271 million as at the end of March 2008.

In 2008, the NSDC has implemented the NSDC Blueprint 2008 that includes 198 key programs with financial commitment of RM3.2 billion. It is a continuance to the 2007 framework. These programs benefited SMEs across all economic sectors, in the areas of enhancing the supporting infrastructure, capacity building and improving access to 
financing. The aim of the 2008 Blueprint was promoting SMEs in the services, primary agriculture and agro-based sectors, in line with the strategies formulated in Ninth Malaysia Plan or RMK9 (Rancangan Malaysia ke-9).

The programs in capacity building focused on entrepreneurship, human capital development, marketing and promotion, and provision of advisory services to SMEs. Some 75,000 SMEs participated in entrepreneurship programs for distributive trade and other strategic sectors and more than 38,000 SMEs have better access to advisory services provided by various Ministries and Agencies through SME Expert Advisory Panel and Technology Awareness and Advisory programs. As for marketing and promotion exertion, Ministry of Entrepreneur and Co-operative Development (MECD) and Malaysia External Trade Development Corporation (MATRADE) have organized several promotional programs locally or abroad for SMEs products and services. Such events offer platform for SMEs to penetrate and widen their target market.

In terms of enhancing supporting infrastructures for SMEs, the government provides more business premises, factories, business stalls and incubation centres. Two major infrastructures are the establishment of Halal Park and center for packaging, distribution and marketing of agriculture products (PUSPRO). These projects create opportunity for SMEs to better market their products at lower production costs. In terms of financing, 2008 blueprint aims for a total of RM70 billion financing to 140,000 SMEs from banking and development financial institutions. In order to accomplish this financing objective, the government implemented other financial assistance programs that includes the rural economy funding scheme and the franchise financing scheme. The Credit Guarantee Corporation Berhad (CGC) has established the SME Credit Bureau that operates as a comprehensive SME information center offering credit reports and credit ratings. This effort facilitates SMEs in obtaining financing at more favorable terms and enhances the competitiveness of SMEs by inculcating a healthy credit culture amongst them.

Furthermore, the council or NSDC has agreed to shift SMEs towards higher value-added industries by encouraging development of knowledge-based SMEs (K-SMEs). K-SMEs are defined as companies with more than $20 \%$ of its staff being knowledge workers, companies that directly use ICT and technology in business processes or for product improvement, companies that adopt innovation and $R \& D$ in business processes or for product development, and companies that provide systematic training and learning of technical skills to their employees. SMEs that have achieved K-SME status will gain fiscal incentives, access to technology funds, capital and financing offered by agencies under the Ministry of Science, Technology and Innovation, quicker intellectual property and patent registration, as well as priority access to government procurement. This measure has made K-SMEs more competitive and viable to manage the pressure of global economic environment.

The council has also set up a special committee to recommend measures to assist SMEs absorbing the impact of rising prices and operational costs in 2008. Stategic plans considered by the committee include tax incentives to encourage SMEs to upgrade their machineries and equipments, adopt new technology, implement development programs to enhance capabilities of SMEs and to reduce their operational costs. In conjunction with recommendation made by the special committee, the council has laid out additional measures aimed at providing avenues for SMEs to seek financial or advisory assistance and enhancing efficiency and productivity of SMEs.

In order to probe rising operational costs that caused financial difficulties, viable SMEs could seek financing from SME Assistance Facility with a total amount of RM700 million established by Bank Negara Malaysia in August 2008. The fund is intended for viable SMEs to continue their business operations and to preserve employment. This financing can be obtained through commercial and Islamic banks, SME Bank, Agro Bank, Bank Rakyat and Exim Bank at 4\% per annum interest charge. SMEs facing cash flow problem may discuss with CGC or their loan providers to restructure outstanding loans and reschedule repayment.

Bank Negara Malaysia and other relevant agencies has provided avenue for SMEs to seek advise on matters pertaining how to better manage cash flow and rising costs. Bank Negara Malaysia has set up One-stop Center on Financial Advisory so that SMEs will have the chance to know more about the available financial and non-financial programs provided by the government. The CGC provides SMEs with advisory services on cost effective measures that may be taken to manage operational costs. Banking institutions play their role by setting up SME Units of the bank to provide information on various sources of financing available, provide advisory services and facilitate the loan application process. The Advisory Center of SME Bank offers similar assistance together with expert advice on marketing, business development, operations and customer services.

In order to enhance efficiency and productivity, SMEs are encouraged to undertake measures to modernize and upgrade machinery, equipment and operation, as well as utilize energy-saving devices. In order to assist SMEs in modernizing their operation and reducing costs of operation, Bank Negara Malaysia has established a RM500 million SME Modernization Facility in form of financing to purchase or upgrade machinery and equipment. SMIDEC has also intensified efforts to provide consultancy to assist SMEs in strengthening their business operation. A program named 'University-SME Internship Program' was introduced to create linkage and cooperation between university and SMEs. Selected final year university students will be attached at participating SMEs, at no cost, for three months to assist them 
in the areas of basic management, financial management, marketing as well as practices and applications of technology. Another program organized by SMIDEC is Skills Upgrading Program. SMEs that are facing the problem of not being able to support their employees for training will have the opportunity to enhance technical skills and capabilities of their employees through this program. The company will have to cover only $20 \%$ of total training costs because SMIDEC has provided another $80 \%$ of the total costs as training grant.

SMIDEC also offers SME Expert Advisory Panel (SEAP) to SMEs. SEAP is a programme implemented to strengthen technical advisory services. SMEs are given on-site assistance by industry experts to transfer their technology know-how and industry experience. Recently, SMIDEC launches the other programme named the Industrial Linkage Programme (ILP) which is aimed at developing domestic SMEs into competitive manufacturers and suppliers of parts and components and related services to MNCs and large companies. This programme is supported and enhanced by SMIDEC's existing financial schemes and developmental programmes. To encourage participation in the ILP, Pioneer Status with tax exemption of 100 per cent on statutory income for five years, or Investment Tax Allowance of 60 per cent on qualifying capital expenditure incurred within a period of five years are provided to eligible SMEs. SMEs must manufacture products or undertake activities in the List of Promoted Activities and Products in an ILP to become qualified for the incentives and supplying to MNCs or large companies. For MNCs or large companies, expenses incurred in developing SMEs such as training, factory auditing and technical assistance to ensure the quality of vendors' products, will be allowed as deduction in the computation of income tax.

In addition to specific programs implemented by the NSDC,SMIDEC and other related agencies, SMEs may also take advantage of suplementary incentives approved by the government. SMEs can acquire or import machinery and equipment that are used directly in their operation for the purpose of modernization since the government has granted import duty exemption. SMEs are also eligible for sales tax exemption if the machinery and equipment are manufactured locally. Another opportunity for SMEs is Energy Efficiency Grant up to RM500,000 per application from SMIDEC. The objective of this incentive is to promote implementation of cost saving measures relating to energy usage at factory premises and operation improvement. SMEs may apply for the grant to purchase equipment or devices related to energy saving.

Bank Negara Malaysia has also announced another financial assistance scheme with total funds of RM2 billion for SMEs to keep on competitive and to survive in the global recession. The scheme can be accessed at any commercial and Islamic banks, SME Bank, Agrobank, Bank Rakyat, EXIM Bank and Bank Simpanan Nasional. Each eligible SME may obtain financing up to RM500,000 for the purpose of business operation such as working capital, project financing and capital expenditures. The CGC will provide credit guarantee on $80 \%$ of the principal and interest charges in order to encourage participation from commercial banks.

\section{Conclusion}

Globalization has made the economy of a nation more exposed to any unfavorable events or crisis since the market has becoming less segmented. The impact of rising oil price and financial crisis in the U.S.A. has spread out to almost every nation in the world that has opened their door for international business. Most country has experienced the mist of recession as businesses are slowing down, productions are diminishing, unemployment rate climbing up, bearish capital market and capital flows stalled. Malaysia experienced similar symptoms and SMEs were hit hard. SMEs, small in its assets, working capital, skilled workforce etc, are affected in larger degree especially those involved with trading and supplying products or services to other businesses. Lower cash flows and limited financing are the major challenges faced by the SMEs during this bearish period.

Nevertheless, the government has recognized the importance of SMEs for the economy and has implemented various policies, action plans and programs to assist them in this difficult circumstances. However, new empirical evidence suggests that policies should not be directed solely to strengthen inter-firm co-operation within SMEs clusters. To be more effective, they should be combined with another set of policies: government interventions at the national level and specific schemes to build up the technological capabilities of SMEs (Albaladejo, 2001). Worth to mention, SMEs in Malaysia are still capable of absorbing the depressing global economic condition due to well structured supporting plans tailored by the government and related agencies. Internal strenghts of the SMEs as a result of the continuous development and innovation as well as knowledgable workforce has also contributed to their resilient.

\section{Future research}

In the nutshell, the study has given an overview analysis of challenges and competitiveness of Malaysia's SMEs in a global business environment. Although it does not reflect the empirical study of SMEs in Malaysia, but at least it contributes an important study by adding more literature regarding SMEs from Malaysia perspective. Based on the limitation of the current research, the study provides few suggestions for future research. First, future research should consider a survey-based research in order to measure the competitiveness of Malaysia's SMESs in facing the global challenges. SMEs registered in the Ministry of International Trade and Industry (MATRADE) and Malaysian Industrial 
Development Authority (MIDA) might be used as the sampling frame in the future study especially SMEs that listed in manufacturing activities. Second, the other data collection method such as in depth interview with the owners or managers of SMEs could also be employed in order to obtain more accurate information pertaining to SMEs issues and challenges.

\section{References}

Abu Bakar, J., Mad, C. A. \& Abdul Latif, R. (2006). Liberalization and globalization: a case of Naza and a lesson to SME. Proceedings of Persidangan Kebangsaan IKS 2006, Kuala Lumpur: Universiti Utara Malaysia.

Alba, M., Diez, L., Olmos, E. \& Rodriguez, R. (2005). Global performance management for small and medium-sized enterprises (GPM-SME). In IFIP International Federation for Information Processing Book Series. Boston: Springer Boston. pp. 1-8.

Albaladejo, M. (2001). Determinants and policies to foster the competitiveness of SME clusters: evidence from Latin America. $Q E H$ Working Paper Series-QEHWPS71. [On-line]. Available: http://www3.qeh.ox.ac.uk/RePEc/qeh/qehwps/qehwps71.pdf.

Anazawa, M. (2004). Sharing of Japanese SMIs experiences. SMIs as the New Source of Growth: Global Productivity Challenges Seminar, 5 August, Kuala Lumpur: Nikko Hotel.

Aris, N. M. (2006). SMEs: building blocks for economic growth. [On-line]. Available: http://www.statistics.gov.my/conference/download.php?cat=1\&id_file $=22$.

Aziz, Z. A. (2000). Globalization and open market- challenges for Bumiputra entrepreneurs. Young Malays Professional Congress, 26 February, Kuala Lumpur.

Bank Negara Malaysia (2008). Statutory requirements. [On-line]. Available: http://www.bnm.gov.my.

Beauchamp, T.L. \& Bowie, N.E. (2004). Ethical theory and business. (7th ed.). New Jersey: Prentice Hall.

Central Bank of Malaysia (2003). A comprehensive framework for the development of small and medium enterprises in Malaysia. [On-line]. Available: http://www.bnm.gov.my.

Coe, N.M., Hess, M., Yeung, H.W., Dicken, P. \& Henderson, J. (2004). 'Globalizing' regional development: a global production networks perspective. Royal Geographical Society, 468-484.

Decker, M., Schiefer, G. \& Bulander, R. (2006). Specific challenges for small and medium-sized enterprises (SME) in M-business: a SME-suitable framework for mobile services. Proceedings of the International Conference on E-Business (ICE-B 2006), Setúbal, Portugal: INSTICC.

Economic Planning Advisory Commission (EPAC). (1995a). Globalisation: issues for Australia. Commission Paper No. 5, Australian Government Publishing Service, Canberra.

Economic Planning Advisory Commission (EPAC). (1995b). Globalisation: old wine in new bottles? Australian Government Publishing Service, Canberra.

Foon, L. S. \& Eu-Gene, S. (2006). The changing of education in the globalized world. Proceedings of Persidangan Kebangsaan IKS 2006, Kuala Lumpur: Universiti Utara Malaysia.

Gomes-Casseres, B. (1997). Alliance strategies of small firms. Small Business Economics, 9(1), 33-44.

Harvie, C. (2004) East Asian SME capacity building, competitiveness and market opportunities in a global economy. [On-line]. Available: http://www.uow.edu.au/commerce/econ/wpapers.html.

Hong, P. \& Jeong, J. (2006). Supply chain management practices of SMEs: from a business growth perspective. Journal of Enterprise Information Management, 19(3), 292-302.

Humprey, J. (2001). Opportunities for SMEs in developing countries to upgrade in a global economy. ILO's in Focus Programme on Small Enterprise Development (IFP-SEED). [On-line]. Available: http://www.inti.gov.ar/cadenasdevalor/oportunidadespyme.pdf.

Indjikian, R. (2003). E-finance for SMEs: global trends and national experiences. The World Bank Conference, Washington: UNCTAD. [On-line]. Available: http://www.unctad.org/ecommerce.

Kitching, J. \& Blackburn, R. (1998). Intellectual property management in the small and medium enterprise (SME). Journal of Small Business and Enterprise Development, 5(4), 327-335.

Knight, G. (2000). Entrepreneurship and marketing strategy: the SME under globalization. Journal of International Marketing, 8(2), 12-32.

Levitt, T. (1983). The globalization of markets. Harvard Business Review, (May/June), 39-49. 
McKnight, D. H. \& Chervany, N. L. (1996). The meaning of trust. [On-line]. Available: http://misrc.umn.edu/wpaper/WorkingPapers/9604.pdf.

McMahon, R. G. P. (2001). Business growth and performance and the financial reporting practices of Australian manufacturing SMEs. Journal of Small Business Management, 39(2), 152-164.

Muhammad, M. Z., Ilias, A., Ghazali, M. F., Chong, R. \& Amin, H. (2008). An analysis of Islamic ethics in small and medium enterprises (SMEs). UNITAR e- Journal, 10(8), 45-54.

Obaidullah, M. (2001). Ethics and efficiency in Islamic stock markets. International Journal of Islamic Financial Services, 3(2), 1-10.

Ritchie, B. \& Brindley, C. (2000). Disintermediation, disintegration and risk in the SME global supply chain. Management Decision, 38(8), 575-583.

Robinson, R. B. (1982). The importance of outsiders in small firm strategic planning. Academy of Management Journal, 80-94.

Saleh, A.S. \& Ndubisi, N.O. (2006). SME development in Malaysia: domestic and global challenges. [On-line]. Available: http://www.uow.edu.au/commerce/econ/wpapers.html.

Samad, N. A. (2007). Positioning Malaysian SMEs in the global. Proceedings of Persidangan Kebangsaan IKS 2007, Kota Kinabalu: Universiti Utara Malaysia.

SMIDEC. (2007). SME development programme. [On-line]. Available: http://www.smidec.gov.my/detailpage.jsp?section=defsme\&level=1.

Stuti, K. I. (2005). Overcoming barriers to innovation for Indian SMEs. Ministry of Small Scale Industries, New Delhi, India. [On-line]. Available: http://74.125.155.132/scholar?q=cache:ZyqqVy8Bof4J:scholar.google.com/+Stuti+\%2B+Overcoming+barriers+to+inn ovation + for + Indian + SMEs\&hl $=$ en.

Teoh, W. M. Y. \& Chong, S. C. (2008). Improving women entrepreneurs in small and medium enterprises in Malaysia: policy recommendations. Communication of The IBIMA, 2, 31-38.

Tetteh, E. \& Burn, J. (2001). Global strategies for SMe-business: applying the SMALL framework. Logistics Information Management, 14 (1/2), 171-180.

Thomas, J. \& Evanson, R. V. (1987). An empirical investigation of association between financial ratio use and small business success. Journal of Business Finance \& Accounting, 14 (4), 555-571.

United Nations Economic Commission for Europe (2004). Entrepreneurship and SMEs: business ethics for start-up entrepreneurs and SMEs. [On-line]. Available: http://www.unece.org/indust/sme/BusinessEthics-final.pdf.

Wafa, S. A., Noordin, R. \& Kim-Man, M. (2005). Strategy and performance of small and medium-size enterprises in Malaysia. Proceedings of the International Conference in Economics and Finance (ICEF), Labuan: Universiti Malaysia Sabah.

Wang, S. D. (2003). The implications of e-financing: implications for SMEs. Bulletin on Asia-Pacific Perspective 2003/2004. New York: United Nations.

Wright, R.W. \& Etemad, H. (2001). SMEs and the global economy. Journal of International Management, 7, 151-154. 
Table 1.1. Category of small and medium enterprises (SMEs)

\begin{tabular}{|c|c|c|}
\hline Category & Sector & Definition \\
\hline \multirow{2}{*}{$\begin{array}{c}\text { Micro } \\
\text { Enterprises }\end{array}$} & $\begin{array}{l}\text { Manufacturing, manufacturing related services and } \\
\text { agriculture industries }\end{array}$ & $\begin{array}{l}\text { Sales Turnover less than RM 250,000 OR less than } 5 \\
\text { employees }\end{array}$ \\
\hline & Services (including ICT) and primary agriculture & $\begin{array}{l}\text { Sales Turnover less than RM 200,000 OR less than } 5 \\
\text { employees }\end{array}$ \\
\hline \multirow{2}{*}{$\begin{array}{c}\text { Small } \\
\text { Enterprises }\end{array}$} & $\begin{array}{l}\text { Manufacturing, manufacturing related services and } \\
\text { agriculture industries }\end{array}$ & $\begin{array}{l}\text { Sales Turnover between RM } 250,000 \text { to less than RM } 10 \\
\text { million OR employees between } 5 \text { to } 50\end{array}$ \\
\hline & Services (including ICT) and primary agriculture & $\begin{array}{l}\text { Sales Turnover between RM } 200,000 \text { to less than RM } 1 \\
\text { million OR employees between } 5 \text { to } 19\end{array}$ \\
\hline \multirow{2}{*}{$\begin{array}{l}\text { Medium } \\
\text { Enterprises }\end{array}$} & $\begin{array}{l}\text { Manufacturing, manufacturing related services and } \\
\text { agriculture industries }\end{array}$ & $\begin{array}{l}\text { Sales Turnover between RM } 10 \text { million to RM } 25 \text { million } \\
\text { OR employees between } 51 \text { to } 150\end{array}$ \\
\hline & Services (including ICT) and primary agriculture & $\begin{array}{l}\text { Sales Turnover between RM } 1 \text { million to RM } 5 \text { million } \\
\text { OR employees between } 20 \text { to } 50\end{array}$ \\
\hline
\end{tabular}

Source: SMEinfo, Retrieved from: http://www.smeinfo.com.my

Table 1.2. Distribution of establishments by sector

\begin{tabular}{|c|c|c|}
\hline Sector & No. of establishments & $\%$ \\
\hline Manufacturing & 85,946 & 5.0 \\
\hline Services & $1,523,842$ & 87.9 \\
\hline Agriculture & 123,762 & 7.1 \\
\hline Total & $1,733,550$ & 100.0 \\
\hline
\end{tabular}

Source: Department of Statistics, Malaysia, Retrieved from: www.statistics.gov.my 